\title{
OPTIMISME DAN DISTRES PSIKOLOGIS PADA PERAWAT SELAMA PANDEMI COVID-19
}

\author{
Dian Agusti Tanjung ${ }^{1}$, Emil Huriani², Dally Rahman ${ }^{3}$ \\ 1Prodi S1 Keperawatan Fakultas Keperawatan Universitas Andalas, Limau Manis Padang \\ 2,3 Bagian KMB-KGD Fakultas Keperawatan Universitas Andalas, Limau Manis Padang. \\ Email: emilhuriani@nrs.unand.ac.id \\ emilhuriani@gmail.com
}

\begin{abstract}
ABSTRAK
Salah satu dampak psikologis yang ditemui saat pandemi Covid-19 adalah distres psikologis yang dialami tenaga kesehatan khususnya perawat. Distres psikologis memunculkan efek membahayakan bagi individu seperti, tuntutan berlebihan yang menguras energi individu sehingga membuat individu menjadi lebih mudah sakit.Tujuan dari penelitian ini adalah untuk mengetahui hubungan ruang bertugas dan optimisme dengan distres psikologis yang meliputi stres, kecemasan dan depresi pada perawat selama pandemi Covid-19 di RS Paru Provinsi Sumatera Barat tahun 2020. Jenis penelitian ini adalah deskripsi korelatif, dengan populasi 35 perawat. Optimisme diukur dengan kuesioner Life Orientation Test-Revised (LOT-R), stres diukur dengan kuesioner Perceived Stress Scale (PSS-10), kecemasan diukur dengan kuesioner General Anxiety Disorder Scale (GAD-7), dan depresi diukur dengan kuesioner Patient Health Questionnaire (PHQ-9). Hasil penelitian menunjukkan terdapat hubungan yang bermakna antara ruang bertugas dengan distres psikologis yaitu stres, kecemasan dan depresi pada perawat selama pandemi Covid-19 dengan nilai $p=0.003$ (stres), $p=0.008$ (kecemasan), $p=0.046$ (depresi) dengan $p<0,05$. Serta terdapat hubungan yang bermakna antara optimisme dengan distres psikologis yaitu stres, kecemasan dan depresi pada perawat selama pandemi Covid-19 dengan nilai $p=<0,05$. Disarankan pada pihak manajemen keperawatan di rumah sakit perlu meningkatkan program manajemen stres bagi tenaga keperawatan, sehingga dapat meminimalisir adanya distres psikologis yang diterima perawat.
\end{abstract}

Kata Kunci: distres psikologis; optimisme; ruang bertugas

\section{OPTIMISM AND PSYCHOLOGICAL DISTRESS IN NURSES DURING THE COVID-19 PANDEMIC}

\begin{abstract}
The psychological impact that is encountered during the Covid-19 pandemic is the psychological distress experienced by health workers, especially nurse. Psychological distress has harmful effects on the individual who experiences it, such as unpleasant or excessive demands that drain the individual's energy, making it easier for the individual to get sick. The purpose of this study was to determine the relationship between department and optimism with psychological distress including perceived stress, anxiety and depression in nurses and to determine the distress that nurses felt during the Covid19 pandemic at the Pulmonology Hospital West Sumatera in 2020. The type of study was a descriptive correlative, with a population of 35 nurses. Optimization was measured using the Life Orientation Test-Revised (LOT-R) questionnaire, perceived stress was measured by the Perceived Stress Scale (PSS-10) questionnaire, anxiety was measured using the General Anxiety Disorder Scale (GAD-7) questionnaire, and depression was measured using the Patient Health Questionnaire (PHQ-9). The results showed that there is a significant relationship between department and psychological distress, perceived stress, anxiety and depression in nurses during the Covid-19 pandemic with a value of $p<0.05$. And there is a significant relationship between optimism and psychological distress, perceived stress, anxiety and depression in nurses during the Covid-19 pandemic. It is suggested that the nursing management at the hospital needs to increase the stress management program for nursing personnel, so that it can minimize the psychological distress received by nurses.
\end{abstract}

Keywords: department; optimism; psychological distress

Jurnal SMART Keperawatan is licensed under a Creative Commons Attribution-ShareAlike 4.0 International License. 


\section{LATAR BELAKANG}

Coronavirus Disease 2019 (Covid-19) menginfeksi hampir seluruh negara di dunia, sehingga Januari 2020 WHO menyatakan dunia masuk kedalam darurat global terkait virus Covid-19 (Sebayang, 2020).Di Indonesia sampai 15 Juli 2020 kasus Covid-19 mencapai sekitar 80 ribu kasus dengan kasus harian yang terus bertambah (Satuan Tugas Penanganan COVID-19, 2020). Tanggal 13 Agustus 2020 setidaknya dilaporkan 4 rumah sakit di Indonesia mengalami penutupan sementara layanan kesehatan karena tenaga medisnya terpapar Covid-19, yaitu RSUD IA Moeis Samarinda Kalimantan Timur, RS Cahaya Medika (RSCM) Praya Lombok Tengah, RS Muyang Kute Bener Meriah Aceh, dan RS Probolinggo Jawa Timur (Kompas, 2020).

Sementara itu, di Sumatera Barat diketahui beberapa rumah sakit menutup layanannya sementara dikarenakan petugas kesehatan yang terpapar Covid-19. Seperti penutupan sementara Rumah Sakit Umum Daerah (RSUD) Padang Panjang tanggal $1 \mathrm{Mei}$ sampai 15 Mei 2020. Halik Malik, juru bicara Ikatan Dokter Indonesia (IDI) menyampaikan bahwa Rumah Sakit banyak yang terpaksa harus membatasi layanan karena adanya petugas yang diistirahatkan, dirawat, dan harus mengurangi jadwal bekerja karena meningkatnya beban di rumah sakit tempatnya bekerja (BBC News Indonesia, 2020).

Pemerintah Indonesia tanggal 29 Februari 2020 hingga 29 Mei 2020 mengeluarkan status darurat bencana dengan jumlah waktu 91 hari terkait pandemi virus ini (Koesmawardhani, 2020). Menurut data pantauan dari Gugus Tugas Percepatan Penanganan Covid-19 per 14 Agustus 2020 di Indonesia telah ditemukan positif Covid-19 sebanyak 135.123 orang, kesembuhan sebanyak 89.618 orang dan meninggal dunia sebanyak 6.021 orang. Data ini terus berubah sampai saat ini (Gugus Tugas Indonesia, 2020).

Menurut IASC (Inter-Agency Standing Committee) kedaruratan memang selalu membuat tertekan, tetapi faktor penyebab tekanan khusus wabah Covid-19 dapat mempengaruhi masyarakat, seperti risiko terinfeksi dan menginfeksi orang lain, terutama jika penularan Covid-19 belum 100\% diketahui dan gejala umum seperti masalah kesehatan lain (mis., demam) bisa disalah artikan sebagai Covid-19 dan menyebabkan rasa takut terinfeksi. Selain itu, bagi tenaga kesehatan garis depan (termasuk perawat, dokter, pengemudi ambulans, petugas identifikasi kasus, dan lainnya) faktor penyebab stres tambahan selama wabah Covid-19 bisa jadi lebih berat (IASC, 2020).

Distress merupakan stres yang memunculkan efek yang membahayakan bagi individu yang mengalaminya seperti: tuntutan yang tidak menyenangkan atau berlebihan yang menguras energi individu sehingga membuatnya menjadi lebih mudah jatuh sakit (Dewi, 2012). Sementara menurut Quick dan Quick, distres yaitu hasil dari respon terhadap stres yang bersifat tidak sehat, negatif, dan destruktif atau bersifat merusak (Waluyo, 2009).

Liu \& Liu membagi distres psikologis menjadi tiga yaitu: perceived stress, anxiety, and depression agar dapat mengevaluasi tekanan psikologis yang disebabkan oleh pandemi Covid-19 secara lebih spesifik(Liu \& Liu, 2020).Distres psikologis diperkirakan sama-sama didahului oleh stresor, seperti adanya permintaan atau kebutuhan yang tidak dapat terpenuhi, hal ini ditulis dalam Canadian Institute for Health Information (2012).

Berdasarkan penelitian yang dilakukan oleh Jie Zhang dkk April 2020 dari Rumah Sakit Zhongshan, Guangdong, China, diketahui pada individu yang memiliki pengalaman Covid-19 terjadi peningkatan prevelensi depresi sebesar 21,1\% (Zhang dkk, 2020). Sementara menurut Liu \&Liu tahun 2020, melaporkan pada tenaga kesehatan yang berada di garis depan mengalami stres sedang hingga berat sebesar 49.1\% tenaga kesehatan garis depan, kecemasan sedang hingga berat $10.7 \%$, dan 12.4\% mengalami depresi berat Selanjutnya, tingkat kecemasan perawat di unit gawat darurat lebih tinggi daripada diruang isolasi atau poliklinik (Liu \& Liu, 2020).

Di Indonesia menurut penelitian yang dilakukan oleh Muliantino dkk tahun 2020 terhadap 535 perawat yang bekerja di rumah 
http://stikesyahoedsmg.ac.id/ojs/index.php/sjkp

sakit selama pandemi Covid-19 dari 24 provinsi di Indonesia ditemukan 23.7\% (127 perawat) memiliki kecemasan sedang, $6.5 \% \quad$ (35 perawat) mengalami stres sedang, dan $8.8 \%$ (47 perawat) mengalami depresi sedang. Penelitian juga menjelaskan bahwa perawat yang bekerja di IGD dan ruang isolasi mengalami kecemasan, stres dan depresi yang lebih tinggi (Muliantino dkk, 2020).

Sementara itu, penelitian yang dilakukan oleh Chang, Rand dan Strunk (2000) menjelaskan bahwa semakin optimis seseorang maka tingkat stres yang mereka miliki semakin rendah. Penelitian sebelumnya menunjukkan bahwa semakin tinggi optimisme individu maka semakin tinggi pula coping stress yang dialami oleh individu tersebut. Sehingga apabila coping stress tinggi juga akan mempengaruhi tingkat stres yang diterima individu menjaid lebih rendah (Ningrum, 2011).

Tenaga perawat memiliki jumlah paling besar dibandingkan dengan tenaga kesehatan lainnya yang ada di RS Paru Sumatera Barat. Hal ini tentu membuat pihak rumah sakit untuk meningkatkan perhatian kepada perawat agar tidak terkena distres psikologis. Oleh karena itu apabila ada sebagian perawat yang mengalami distres, maka akan berdampak terhadap kualitas pelayanan keperawatan yang diberikan.

Dalam kurun 6 bulan yaitu dari bulan Juli 2019 sampai Desember 2020 jumlah pasien baru yang berkunjung ke RS Paru Sumatera Barat berjumlah 1012 orang. Hal ini mengalami peningkatan terhitung mulai Januari 2020 sampai Juni 2020 terdapat 1790 jumlah kunjungan. Dengan adanya pandemi Covid-19 yang gejalanya menyerupai pasien yang umumnya berobat ke RS Paru Sumatera Barat, maka hal ini dapat menambah tingkat distres yang dirasakan oleh perawat di RS Paru Sumatera Barat.

Berdasarkan hasil wawancara pendahuluan dengan perawat di RS Paru Sumatera Barat diperoleh kesimpulan bahwa tingkat distres psikologis yang dirasakan perawat di RS Paru Sumatera Barat sangat bervariasi tergantung dari ruangan bertugas dan optimisme yang dirasakan perawat di RS Paru Sumatera Barat selama pandemi Covid-
19. Seperti ditemukan perawat yang bertugas di rawat jalan cenderung lebih cemas dan stres daripada IGD dan rawat inap selama bertugas di pelayanan. Sementara perawat yang berada di rawat inap cenderung lebih bersikap optimis dalam bertugas daripada perawat di rawat jalan. Dari hasil wawancara terhadap 6 perawat, dengan karakteristik ruang bertugas yang berbeda juga ditemukan bahwa selama pandemi Covid-19 ada perawat yang mengalami sulit tidur, gugup, kecemasan, dan beberapa gejala distres psikologis lainnya yang bahkan menggangu aktifitas atau kegiatan harian perawat tersebut.

Berdasarkan uraian di atas penulis berminat untuk melakukan suatu penelitian mengenai hubungan ruang bertugas dan optimisme dengan distres psikologis pada perawat selama pandemi Covid-19 di RS Paru Provinsi Sumatera Barat. Rekomendasi etik penelitian ini telah diberikan oleh Komite Etik Penelitian Fakultas Keperawatan Universitas Andalas No 281/KEP/FK/2020.

\section{METODE}

Desain penelitian ini menggunakan desain penelitian deskripsi korelatif yang bertujuan untuk mengetahui hubungan ruang bertugas dan optimisme dengan distres psikologis yang meliputi stres, kecemasan dan depresi pada perawat dan menentukan distres yang dirasakan perawat selama pandemi Covid-19 di RS Paru Provinsi Sumatera Barat Tahun 2020.

Populasi dalam penelitian ini adalah 35 perawat yang bekerja di RS Paru Provinsi Sumatera Barat. Peneliti mengambil sampel dengan metode total sampling.

Alat pengumpulan data yang digunakan pada penelitian ini adalah kuesioner, yaitu optimisme diukur dengan kuesioner Life Orientation Test-Revised (LOT-R) (Scheier, Carver, and Bridges, M.W. 1994), stres diukur dengan kuesioner Perceived Stress Scale (PSS-10) (Wang, Chen, Boyd, Zhang, Jia,Qiu, \& Xiao, 2011), kecemasan diukur dengan kuesioner General Anxiety Disorder Scale (GAD-7) (Spitzer, Kroenke, Williams, \& Lo, 2015), dan depresi diukur dengan kuesioner Patient Health Questionnaire (PHQ-9) (Kroenke, Spitzer, Wiliams, 2001). 
Pengumpulan data penelitian dengan izin RS Paru Sumatera Barat dan dilanjutkan penyebaran kuesioner. Peneliti melakukan pendekatan kepada calon responden untuk meminta ketersedian menjadi responden penelitian. Jika calon responden setuju untuk menjadi responden, maka peneliti meminta responden untuk menandatangi lembar persetujuan responden. Respoden diberikan waktu untuk mengisi kuesioner selama \pm 30 menit.Apabila responden mengalami kesulitan dalam mengisi kuesioner maka peneliti akan membantu menjelaskannya. Kuesioner yang telah diisi oleh responden dikembalikan kepada peneliti.Semua kuesioner yang telah diisi dikumpulkan untuk diseleksi dan dilakukan pengolahan data.

\section{HASIL}

Karakteristik responden yang disajikan terdiri dari usia, jenis kelamin, pendidikan terakhir, dan status pernikahan. Berdasarkan Tabel 1 disebutkan bahwa perawat yang bekerja di RS Paru Sumatera Barat hampir separuh berada pada rentang usia 30-40 tahun sebanyak 19 perawat (54.3\%), berjenis kelamin perempuan sebanyak 30 perawat (85.7\%), berpendidikan terakhir S1 Keperawatan + Ners sebanyak 18 perawat $(51.4 \%)$, dan telah menikah sebanyak 29 perawat (82.9\%).

Tabel1. Distribusi frekuensi karakteristik responden $(n=35)$

\begin{tabular}{lcc}
\hline \multicolumn{1}{c}{ Karakteristik Responden } & $\mathrm{f}$ & $\%$ \\
\hline Usia & & \\
$\quad$ <30 tahun & 5 & 14.3 \\
$30-40$ tahun & 19 & 54.3 \\
$\quad \geq 40$ tahun & 11 & 31.4 \\
Jenis Kelamin & & \\
$\quad$ Laki-laki & 5 & 14.3 \\
$\quad$ Perempuan & 30 & 85.7 \\
Pendidikan Terakhir & & \\
$\quad$ D3 Keperawatan & 17 & 48.6 \\
$\quad$ S1Keperawatan + Ners & 18 & 51.4 \\
Status Pernikahan & & \\
$\quad$ Belum Menikah & 4 & 11.4 \\
$\quad$ Menikah & 29 & 82.9 \\
$\quad$ Cerai & 2 & 5.7 \\
\hline
\end{tabular}

Tabel 2. Distres psikologis (stres, kecemasan dan depresi) pada perawat selama Pandemi Covid-19 ( $\mathrm{n}=35$ )

\begin{tabular}{lcc}
\hline \multicolumn{1}{c}{ Distres Psikologis } & $\mathrm{f}$ & $\%$ \\
\hline Stres & & \\
$\quad$ Ringan & 2 & 5.7 \\
Sedang & 16 & 45.7 \\
$\quad$ Berat & 17 & 48.6 \\
Kecemasan & & \\
$\quad$ Ringan & 10 & 28.6 \\
$\quad$ Sedang & 12 & 34.3 \\
$\quad$ Berat & 13 & 37.1 \\
Depresi & & \\
Minimal & 15 & 42.9 \\
$\quad$ Ringan & 11 & 31.4 \\
$\quad$ Sedang & 9 & 25.7 \\
\hline
\end{tabular}

Berdasarkan Tabel 2 dapat dilihat bahwa tingkat stres berat hampir separuh perawat mengalaminya yaitu sebanyak $48.6 \%$ perawat, untuk kecemasan berat dialami oleh $37.1 \%$ perawat dan untuk depresi minimal dialami oleh 42.9\% perawat yang bekerja di RS Paru Provinsi Sumatera Barat selama pandemi Covid-19.

Berdasarkan ruang bertugas perawat, hampir merata disetiap ruang unit pelayanan kesehatan, salah satunya adalah IGD sebanyak $34.3 \%$ perawat yang bekerja selama pandemi Covid-19.

Tabel 3. Optimisme Perawat Selama Pandemi Covid-19 ( $\mathrm{n}=35$ )

\begin{tabular}{|c|c|c|}
\hline Optimisme Perawat & $f$ & $\%$ \\
\hline Rendah & 13 & 37.1 \\
\hline Tinggi & 22 & 62.9 \\
\hline
\end{tabular}

Berdasarkan Tabel 3 dapat dilihat bahwa tingkat optimisme perawat yang bekerja di RS Paru Provinsi Sumatera Barat adalah tinggi sebanyak 22 perawat (62.9\%).

Berdasarkan Tabel 4 dapat diketahui bahwa terdapat hubungan ruang bertugas dengan stres pada perawat selama pandemi Covid-19 di RS Paru Sumatera Barat dengan nilai $p=0.003(p<0,05)$. Selain itu, juga terdapat hubungan optimisme dengan stres pada perawat selama pandemi Covid-19 dengan nilai $p=0.000(p<0,05)$.

Berdasarkan Tabel 5, terdapat hubungan antara ruang bertugas dan optimisme dengan kecemasan pada perawat selama pandemi 
http://stikesyahoedsmg.ac.id/ojs/index.php/sjkp

Covid-19 di RS Paru Sumatera Barat dengan nilai $p=0.008 \quad(p<0,05)$ terdapat hubungan antara optimisme dengan kecemasan pada perawat selama pandemi Covid-19 dengan nilai $p=0.000(p<0,05)$.

Berdasarkan Tabel 6 diketahui bahwa terdapat hubungan antara ruang bertugas dengan depresi pada perawat selama pandemi Covid-19 dengan nilai $p=0.046(p<0,05)$ dan terdapat hubungan antara optimisme dengan depresi pada perawat selama pandemi Covid19 dengan nilai $p=0.000(p<0,05)$.

Tabel 4. Hubungan ruang bertugas dan optimisme dengan stres pada perawat selama Pandemi Covid-19

\begin{tabular}{|c|c|c|c|c|c|c|c|c|c|}
\hline & \multicolumn{6}{|c|}{ Stres } & \multirow{2}{*}{\multicolumn{2}{|c|}{ Jumlah }} & \multirow[t]{3}{*}{$P$} \\
\hline & \multicolumn{2}{|c|}{ Ringan } & \multicolumn{2}{|c|}{ Sedang } & \multicolumn{2}{|c|}{ Berat } & & & \\
\hline & $f$ & $\%$ & $f$ & $\%$ & $f$ & $\%$ & $f$ & $\%$ & \\
\hline \multicolumn{10}{|c|}{ Ruang Bertugas } \\
\hline IGD & 1 & 8.3 & 5 & 41.7 & 6 & 50.0 & 12 & 100 & 0.003 \\
\hline Rajal & 0 & 0 & 1 & 9.1 & 10 & 90.9 & 11 & 100 & \\
\hline Ranap & 1 & 8.3 & 10 & 83.3 & 1 & 8.3 & 12 & 100 & \\
\hline \multicolumn{10}{|c|}{ Optimisme } \\
\hline Rendah & 0 & 0.0 & 0 & 0.0 & 13 & 100 & 13 & 100 & 0.000 \\
\hline Tinggi & 2 & 9.1 & 16 & 72.7 & 4 & 18.2 & 22 & 100 & \\
\hline
\end{tabular}

Tabel 5. Hubungan ruang bertugas dan optimisme dengan kecemasan pada perawat selama Pandemi Covid-19

\begin{tabular}{|c|c|c|c|c|c|c|c|c|c|}
\hline & \multicolumn{6}{|c|}{ Kecemasan } & \multirow{2}{*}{\multicolumn{2}{|c|}{ Jumlah }} & \multirow{3}{*}{$P$ value } \\
\hline & \multicolumn{2}{|c|}{ Ringan } & \multicolumn{2}{|c|}{ Sedang } & \multicolumn{2}{|c|}{ Berat } & & & \\
\hline & $f$ & $\%$ & $f$ & $\%$ & $f$ & $\%$ & $f$ & $\%$ & \\
\hline Ruang Bertugas & & & & & & & & & \multirow{4}{*}{0.008} \\
\hline IGD & 5 & 41.7 & 3 & 25.5 & 4 & 33.3 & 12 & 100 & \\
\hline Rajal & 2 & 18.2 & 1 & 9.1 & 8 & 72.7 & 11 & 100 & \\
\hline Ranap & 3 & 25.5 & 8 & 66.7 & 1 & 8.3 & 12 & 100 & \\
\hline \multicolumn{10}{|l|}{ Optimisme } \\
\hline Rendah & 0 & 0.0 & 0 & 0.0 & 13 & 100 & 13 & 100 & 0.000 \\
\hline Tinggi & 10 & 45.5 & 12 & 54.5 & 0 & 0 & 22 & 100 & \\
\hline
\end{tabular}

Tabel 6. Hubungan ruang bertugas dan optimisme dengan depresi padaperawat selama PandemiCovid19

\begin{tabular}{|c|c|c|c|c|c|c|c|c|c|}
\hline & \multicolumn{6}{|c|}{ Depresi } & \multirow{2}{*}{\multicolumn{2}{|c|}{ Jumlah }} & \multirow{3}{*}{$P$ value } \\
\hline & \multicolumn{2}{|c|}{ Ringan } & \multicolumn{2}{|c|}{ Sedang } & \multicolumn{2}{|c|}{ Berat } & & & \\
\hline & $f$ & $\%$ & $f$ & $\%$ & $f$ & $\%$ & $f$ & $\%$ & \\
\hline \multicolumn{10}{|l|}{ Ruang Bertugas } \\
\hline IGD & 3 & 25.0 & 6 & 50.0 & 3 & 25.0 & 12 & 100 & \multirow{3}{*}{0.046} \\
\hline Rajal & 3 & 27.3 & 3 & 27.3 & 5 & 45.5 & 11 & 100 & \\
\hline Ranap & 9 & 75.0 & 2 & 16.7 & 1 & 8.3 & 12 & 100 & \\
\hline \multicolumn{10}{|l|}{ Optimisme } \\
\hline Rendah & 0 & 0.0 & 4 & 30.8 & 9 & 69.2 & 13 & 100 & \multirow[t]{2}{*}{0.000} \\
\hline Tinggi & 15 & 68.2 & 7 & 31.8 & 0 & 0.0 & 22 & 100 & \\
\hline
\end{tabular}

\section{PEMBAHASAN}

Berdasarkan hasil penelitian secara keseluruhan ditemukan adanya gejala distres psikologis, yaitu stres, kecemasan dan depresi pada perawat selama pandemi Covid-19 di RS Paru Sumatera Barat. Namun demikian, perawat tetap melaksanakan pelayanan keperawatan atau tugasnya ditengah pandemi Covid-19. Stres, kecemasan, dan depresi yang terjadi ini diduga tidak hanya dikarenakan oleh resiko yang dialami terkait infeksi Covid-19 tetapi juga disebabkan karena adanya tuntutan pekerjaan, risiko pemotongan tunjangan yang diterima perawat jika tidak bekerja, dan bonus yang diterima perawat jika bekerja selama pandemi Covid-19 ini.

Sementara itu, berdasarkan karakteristik responden ditemukan 9 dari 19 perawat yang 
berada direntang usia 30-40 tahun mengalami stres berat. Selanjutnya dari 30 perawat perempuan ditemukan 16 diantaranya mengalami stres berat, untuk kategori pendidikan terakhir S1 Keperawatan+ners ditemukan 11 perawat dari total 18 perawat yang memiliki pendidikan terakhir S1 Keperawatan dan Ners memiliki stres berat, dan dari status pernikahan ditemukan 16 perawat yang telah menikah mengalami stres berat dengan total 29 perawat yang telah menikah.

Sementara itu untuk kecemasan berdasarkan karakteristik responden berupa umur dengan 19 perawat rentang umur 30-40 tahun ditemukan 8 perawat memiliki kecemasan berat dan dari 30 perawat perempuan ditemukan 18 diantaranya mengalami kecemasan berat, untuk kategori pendidikan terakhir S1 Keperawatan+ners ditemukan 10 perawat dari total 18 perawat yang memiliki pendidikan terkahir S1 Keperawatan+Ners memiliki kecemasan berat, dan dari status pernikahan ditemukan 12 perawat yang telah menikah mengalami kecemasan berat dengan total 29 perawat yang telah menikah.

Selanjutnya pada distres psikologis berupa depresi berdasarkan karakteristik responden berupa umur dengan rentang umur 30-40 tahun ditemukan 7 perawat memiliki depresi minimal dari total 19 perawat dan dari 30 perawat perempuan ditemukan 11 perawat diantaranya mengalami depresi ringan, untuk kategori pendidikan terakhir D3 Keperawatan ditemukan 11 perawat dari total 17 perawat memiliki depresi minimal, dan dari status pernikahan ditemukan 11 perawat yang telah menikah mengalami depresi minimal dengan total 29 perawat yang telah menikah.

Berdasarkan hasil penelitian, umur 30-40 lebih dominan mengalami distres psikologis, dengan jenis kelamin perempuan lebih rentan mengalami distres psikologis. Hal ini disebabkan karena respon fisiologis yang berbeda antara laki-laki dan perempuan. Pada saat perempuan menghadapi stres, tubuh akan memberikan respon fisiologis berupa aktifitas dari beberapa hormon dan neurotransmitter di dalam otak. Lebih lanjut lagi perempuan lebih menderita stres daripada laki-laki disebabkan karena prolaktin perempuan lebih tinggi daripada laki-laki.Hormon ini memberikan umpan balik negatif pada otak sehingga dapat meningkatkan trauma emosional dan stres fisik (Crowin, 2007).Hal ini sejalan dengan penelitian Gunawati (2006) yang mengemukakan bahwa secara umum wanita mengalami stres 30\% lebih tinggi daripada lakilaki.

Hasil penelitian dengan karakteristik responden yaitu pendidikan terakhir S1 Keperawatan+Ners dan D3 Keperawatan memperoleh hasil yang bervariasi terhadap gejala distres psikologis yang dirasakan perawat pada pandemi Covid-19. Sehingga tidak dapat disimpulkan bahwa status pendidikan terakhir berpengaruh terhadap distres psikologis yang dialami oleh perawat.

Selanjutnya pada karakteristik status pernikahan, hampir setengah perawat yang telah menikah mengalami distres psikologis berupa stres, kecemasan dan depresi.Hal ini dapat disebabkan oleh tekanan diluar pekerjaan, seperti keadaan rumah tangga yang dihadapi oleh perawat tersebut. Hal ini sejalan dengan penelitian Martini (2012) yang menyatakan stres sedang lebih banyak dialami oleh perawat yang sudah menikah (90\%). Hal ini disebabkan karena permasalahan yang sering terjadi di keluarga, terutama karena sebagian besar responden merupakan keluarga muda yang masih memiliki anak balita. Kondisi keluarga yang membutuhkan perhatian khusus seperti pada saat anak atau pasangan sakit sementara harus tetap bekerja sehingga dapat menjadi stres tersendiri bagi perawat yang sudah berkeluarga (Martini, 2012). Hal ini didukung oleh pernyataan Santrock (dalam Martini, 2012) yang menyatakan bahwa keluarga dapat menjadi salah satu faktor yang dapat menjadi pencetus terjadinya stres.

Ruang bertugas dari data penelitian ditemukan rawat jalan lebih dominan mengalami distres psikologis. Sehingga terdapat perbedaan hasil penelitian dari penelitian sebelumnya. Seperti penelitian yang dilakukan oleh Liu dkk (2020) yang memaparkan hampir semua tenaga kesehatan 


\section{http://stikesyahoedsmg.ac.id/ojs/index.php/sjkp}

yang berada di garis depan (IGD) mengalami stres, kecemasan dan depresi. Perbedaan ini dapat disebabkan karena adanya perbedaan lingkungan kerja atau tuntutan di setiap ruang bertugas perawat selama pandemi Covid-19.

Beberapa faktor yang menyebabkan terjadinya peningkatan distres psikologis pada perawat yang bertugas di Rawat Jalan diantaranya yaitu, peningkatan jumlah pasien rawat jalan, alur pelayanan kesehatan yang berubah, mobilisasi yang tinggi di rawat jalan, dan masih ditemuinya kekurangan APD pada saat pelayanan kesehatan. Selanjutnya untuk perawat yang bertugas di IGD ditemukan kekurangan APD dan adanya perubahan pada alur penerimaan pasien gawat darurat. Sementara itu, perawat yang bertugas di Rawat Jalan memaparkan bahwa ruang rawatan telah dikhususkan untuk merawat pasien terdiagnosa TB MDR dengan jangkauan se-Sumatera Tengah sehingga hal ini juga menambah beban kerja yang diterima oleh perawat Rawat Jalan. Selanjutnya pada faktor internal seperti mekanisme koping individu dan faktor eksternal seperti tuntutan tugas yang tinggi juga dapat mempengaruhi tingkat distres yang dialami oleh perawat.

Miller menyatakan bahwa distres psikologis dapat mengganggu fungsi seseorang dalam melakukan aktifitas seharihari (Miller, 2011). Hal ini tentu juga dirasakan oleh perawat yang bekerja di RS Paru Provinsi Sumatera Barat di tengah pandemi Covid19.Perawat yang mengalami distres psikologis dituntut untuk tetap bekerja saat pandemi Covid-19, hal ini dapat berdampak terhadap pemberian layanan kesehatan.Sementara kepada perawat sendiri, hal ini dapat menyebabkan perawat mudah sakit karena tekanan distres psikologis yang di rasakan saat bekerja. Beberapa perawat mengeluhkan kesulitan tidur, sulit berkonsentrasi, menjadi mudah marah, dan sering merasa cemas. Hal ini sejalan dengan pendapat Wheaton (dalam Dimeitri, Hutapea dan Mashoedi, 2019) yang menjelaskan bahwa distres psikologis berpengaruh pada fungsi sosial dan kehidupan individu sehari-hari. Myrowsky dan Ross (dalam Sangitan, 2012) juga menyebutkan bahwa individu yang mengalami kecemasan juga mengalami ketegangan, gelisah, khawatir, mudah marah dan ketakutan.

Untuk mengatasi hal tersebut pihak manajemen keperawatan di rumah sakit perlu melaksanakan kegiatan relaksasi, penyegaran ilmu terkait virus Covid-19 dan pemberian bonus tambahan secara finansial jika diperlukan. Sehingga dapat meminimalisir adanya distres psikologis yang diterima perawat selama bekerja pada pandemi Covid19 ini.

Berdasarkan hasil penelitian ditemukan perawat yang bekerja di ruang IGD, Rawat Jalan dan Rawat Inap hampir merata di RS Paru Sumatera Barat. Di IGD terdapat 12 perawat (34.3\%), Rawat Jalan 11 perawat (31.4\%) dan Rawat Inap 12 perawat (34.3\%). Pemilihan perawat yang bekerja di setiap ruangan biasanya didasarkan pada faktor umur dan kebijakan rumah sakit. Perawat yang bertugas di IGD umumnya didominasi oleh perawat yang berusia 30-40 tahun, di Rawat Jalan didominasi oleh perawat yang bermur diatas 40 tahun dan di Rawat Inap di dominasi oleh umur 30-40 tahun. Pembagian penempatan ruang bertugas di RS Paru Sumatera Barat juga dipengaruhi oleh kebijakan rumah sakit. Salah satu kebijakan rumah sakit terkait penempatan penugasan perawat adalah pada tahun 2019 yaitu pemindahan salah satu perawat rawat inap ke rawat jalan sebagai tenaga tambahan untuk ruangan TB MDR di rawat jalan.

Rotasi ruangan hampir jarang terjadi di RS Paru Sumatera Barat. Hal ini tentu dapat menyebabkan kejenuhan perawat dan meningkatnya beban kerja tanpa adanya perubahan lingkungan kerja. Martini (2012) dalam penelitian gambaran tingkat stres kerja perawat di ruang rawat inap RS Paru Dr. Moehammad Goenawan Partowodogdo Cisarua Bogor (RSPG) memaparkan bahwa 69 perawat dari 80 perawat di ruang rawat inap RSPG mengalami tingkat stres kerja sedang dengan masa kerja 6 bulan sampai 3 tahun sebanyak 50\%. Mahastuti dkk (2017) dalam Perbedaan stres kerja pada perawat di ruang unit gawat darurat dengan perawat di ruang rawat inap Rumah Sakit "S" di Kota Denpasar tahun 2017 menjelaskan bahwa 39 perawat 
(67.2\%) yang bekerja di UGD dan 29 perawat yang bekerja di rawat inap (50\%) mengalami stres sedang.

Berdasarkan hasil penelitian secara keseluruhan ditemukan 22 perawat memiliki optimisme tinggi dan 13 perawat memiliki optimisme rendah. Kuesioner yang digunakan dalam penelitian ini adalah Life Orientation Test-Revised (LOT-R) dengan nilai pertanyaan tertinggi sebanyak 139 poin (20.3\%) responden menyatakan berharap hal-hal baik akan sering terjadi kepada dirinya daripada hal-hal yang buruk. Hal ini sesuai dengan penelitian sebelumnya yang menjelaskan bahwa semakin optimis seseorang maka tingkat stres yang mereka miliki semakin rendah (Chang, Rand dan Strunk, 2000). Hal ini juga sejalan dengan penelitian sebelumnya yang menjelaskan bahwa semakin tinggi optimisme individu maka semakin tinggi pula coping stress yang dialami oleh individu tersebut. Sehingga apabila coping stress tinggi juga akan mempengaruhi tingkat stres yang diterima individu menjadi lebih rendah (Ningrum, 2011).

Berdasarkan hasil penelitian ini, ditemukan 22 perawat yang memiliki optimisme tinggi masih mengalami stres, kecemasan dan depresi. Responden yang mengalami distres psikologis yaitu stres, kecemasan dan depresi dipengaruhi oleh beberapa karakteristik responden seperti, usia, jenis kelamin, pendidikan terakhir dan status pernikahan.

Tingkat optimisme dapat dipengaruhi oleh pengalaman pribadi individu dan pengalaman dari orang sekitar individu. Semakin banyak pengalaman yang dimiliki individu maka kemampuan dalam menyelesaikan suatu masalah juga akan semakin tinggi. Hal ini dapat dilihat dari usia individu. Hal ini sejalan dengan penelitian yang dilakukan oleh Komalasari (2018) yang menyebutkan usia dewasa (30-40 tahun) memiliki tingkat optimisme lebih tinggi karena memandang bahwa pengalaman masa lalunya sebagai sesuatu yang positif dan berguna untuk di masa depan.

Berdasarkan hasil statistik didapatkan bahwa terdapat hubungan yang bermakna antara ruang bertugas dengan distres psikologis yaitu stres, kecemasan dan depresi pada perawat selama pandemi Covid-19. Penelitian ini didukung oleh penelitian Liu, et al (2020) yang menunjukkan bahwa tenaga kesehatan yang berada di garis depan mengalami stres sedang hingga berat sebesar $49.1 \%$ tenaga kesehatan garis depan, kecemasan sedang hingga berat $10.7 \%$, dan 12.4\% mengalami depresi berat (Liu dkk, 2020). Selanjutnya berdasarkan penelitian Liu \& Liu tahun 2020 diketahui tingkat kecemasan perawat di unit gawat darurat lebih tinggi daripada diruang isolasi atau poliklinik (Liu \& Liu, 2020). Di Indonesia menurut penelitian yang dilakukan oleh Muliantino (2020) terhadap 535 perawat yang bekerja di rumah sakit selama pandemi Covid-19 dari 24 provinsi di Indonesia ditemukan 23.7\% (127 perawat) memiliki kecemasan sedang, 6.5\% (35 perawat) mengalami stres sedang, dan $8.8 \%$ (47 perawat) mengalami depresi sedang. Penelitian juga menjelaskan bahwa perawat yang bekerja di IGD dan ruang isolasi mengalami kecemasan, stres dan depresi yang lebih tinggi (Muliantino dkk, 2020).

WHO atau World Health Organization pada 11 Februari 2020 menyatakan dunia masuk kedalam darurat global terkait virus Covid-19 dan Covid-19 sebagai pandemi di dunia (Montalvan, 2020). Hal ini memicu terjadinya distres psikologis bagi tenaga kesehatan khususnya perawat. Distress psikologis merupakan stres yang memunculkan efek yang membahayakan bagi individu yang mengalaminya seperti: tuntutan yang tidak menyenangkan atau berlebihan yang menguras energi individu sehingga membuatnya menjadi lebih mudah jatuh sakit (Dewi, 2012).

Pada penelitian ini didapatkan distres psikologis, yaitu stres, kecemasan dan depresi hampir terjadi di ruang Rawat Jalan dengan 10 perawat $(90.9 \%)$ mengalami stres berat, 8 perawat $(72.7 \%)$ mengalami kecemasan berat dan 5 perawat $(45.5 \%)$ mengalami depresi sedang. Perawat juga mengeluhkan adanya resiko tertular covid-19, stok APD pada masa pandemi tidak memadai, dan adanya perubahan pelayanan kesehatan di rumah sakit, seperti SOP pelayanan kesehatan juga 
menambah tekanan yang diterima oleh perawat.

Menurut penelitian Liu dkk (2020) menunjukkan bahwa tingkat kecemasan umum petugas kesehatan di unit gawat darurat secara signifikan lebih tinggi daripada petugas kesehatan di bangsal isolasi atau klinik demam. Hal ini berbanding terbalik dengan hasil penelitian yang didapatkan oleh peneliti. Ditemukan distres psikologis berupa stres, kecemasan, dan depresi hampir terjadi di rawat jalan dengan $90.9 \%$ perawat mengalami stres berat, $72.7 \%$ mengalami kecemasan berat, dan $45.5 \%$ perawat mengalami depresi sidang.

Perbedaan ini dapat terjadi karena beberapa faktor seperti faktor internal dan eksternal yang di alami oleh perawat tersebut. Faktor internal dapat berupa usia, jenis kelamin, status pernikahan, pendidikan terakhir dan mekanisme koping yang dimiliki oleh perawat. Sementara itu untuk faktor eksternal dapat berupa tuntutan lingkungan kerja yang berlebih seperti peningkatan jumlah pasien yang berobat dan kekurangan APD oleh petugas rawat jalan. Hal ini sesuai dengan yang dijelaskan oleh Azzahra(2017), yang menjelaskan bahwa ada dua faktor yang mempengaruhi distres psikologis yaitu faktor interpersonal (kepribadian) dan faktor situasional berupa fisiologis, pengaruh kognitif, dan sosial.

Untuk mengatasi hal tersebut pihak manajemen keperawatan di rumah sakit perlu melaksanakan kegiatan relaksasi atau mengadakan rotasi ruangan untuk tenaga keperawatan, sehingga dapat meminimalisir adanya distres psikologis yang diterima perawat. Sehingga jika hal tersebut di laksanakan maka akan berdampak baik juga bagi seluruh tenaga kesehatan dan pelayanan yang diberikan kepada pasien.

Selanjutnya, terdapat hubungan yang bermakna antara optimisme dengan distres psikologis yaitu stres, kecemasan dan depresi pada perawat selama pandemi Covid-19. Penelitian ini didukung oleh penelitian Chang, Rand dan Strunk (2000) yang menjelaskan bahwa semakin optimis seseorang maka tingkat stres yang mereka miliki semakin rendah.
Scheier dan Carver menjelaskan bahwa optimisme adalah keyakinan umum bahwa akan terjadi hal yang baik, individu yang optimis merupakan individu yang cenderung berkeyakinan positif terhadap masa depan (dalam Assyahidah 2015). Terdapat dua faktor yang dapat mempengaruhi optimisme, yaitu faktor internal dan eksternal. Faktor internal terdiri dari temperamen, self-esteem, selfefficacy, dan pengalaman. Fakor eksternal terdiri dari keluarga, kondisi sosial ekonomi, ketersediaan sumber daya, budaya dan media (Rothbarh, Ahadi, Evans, 2000 dalam Assyahidah 2015).

Pada penelitian ini didapatkan distres psikologis, yaitu stres, kecemasan dan depresi hampir terjadi pada perawat yang memiliki tingkat optimisme rendah dengan 13 perawat (100\%) mengalami stres berat, kecemasan berat dan depresi sedang. Sementara 22 perawat yang memiliki optimisme tinggi mengalami stres sedang (81.8\%), kecemasan sedang (63.6\%) dan depresi minimal (72.7\%). $\mathrm{Hal}$ ini sejalan dengan penelitian yang sebelumnya yang menjelaskan bahwa semakin tinggi optimisme individu maka semakin tinggi pula coping stress yang dialami oleh individu tersebut. Sehingga apabila coping stress tinggi juga akan mempengaruhi tingkat stres yang diterima individu menjaid lebih rendah (Ningrum, 2011).

Berdasarkan penelitian yang ditemukan pada 22 perawat yang memiliki optimisme tinggi masih ditemukan perawat yang mengalami stres sedang (81.8\%), kecemasan sedang (63.6\%) dan depresi minimal (72.7\%). Terdapat beberapa perbedaan karakteristik seperti usia, jenis kelamin, pendidikan terakhir, ruang bertugas, dan status pernikahan yang mempengaruhi tingkat optimisme perawat. Pada perawat dengan rentang usia 30-40 tahun ditemukan 11 perawat memiliki optimisme tinggi, dengan jenis kelamin 17 perawat perempuan, 14 perawat berpendidikan terakhir D3 Keperawatan, 11 perawat bertugas di ruang rawat inap dan 17 perawat yang memiliki optimisme tinggi telah menikah.

Perbedaan tingkat optimisme pada perawat dapat dipengaruhi oleh faktor internal dan eksternal.Salah satu faktor internal seperti 
mekanisme pengendalian diri (coping) yang dimiliki oleh individu tersebut. Hal ini sejalan dengan penelitian yang dilakukan oleh Pranandari (2012) yang menunjukkan bahwa individu yang optimis lebih sering mengatasi stres dengan mekanisme coping. Selanjutnya pada faktor internal seperti status pernikahan juga mempengaruhi tingkat optimisme yang dimiliki oleh individu.Umumnya individu yang telah menikah memiliki dukungan sosial yang baik dari pasangannya, sehingga mempengaruhi tingkat optimisme yang dimiliki oleh individu tersebut.Karadesmas (dalam Santoso \& Setiawan, 2018) menjelaskan bahwa dukungan sosial dapat mempengaruhi kondisi afektif seseorang yang berperan dalam mendorong terciptanya rasa aman dan nyaman pada individu ditengah peristiwa apapun, termasuk peristiwa berat dalam kehidupannya.Hal ini sejalan dengan penelitian Komalasari (2018) yang menunjukkan bahwa individu yang memiliki optimisme tinggi didominasi oleh mereka yang telah menikah.

Berdasarkan hasil analisis data penelitian, responden didominasi oleh perawat yang berusia 30-40 tahun sebanyak 19 perawat (54.3\%). Menurut Papalia, Feldman dan Martorell (2014) usia ini termasuk kategori usia dewasa. Meskipun sebagian besar individu membutuhkan waktu yang lama dalam memproses informasi pada usia ini, namun pada saat menghadapi masalah individu tersebut dapat dengan sigap menentukan solusi dari masalah tersebut berdasarkan pengalaman di masa lalu. Hal ini sejalan dengan penelitian Komalasari (2018) yang menjelaskan bahwa semakin banyak pengalaman yang dimiliki seseorang, maka kemampuan diri dalam menyelesaikan masalah juga semakin tinggi.Untuk mengatasi hal tersebut pihak manajemen keperawatan di rumah sakit perlu meningkatkan program manajemen stres bagi tenaga keperawatan, memfasilitasi pembaruan ilmu terkait Covid-19 dan peningkatan motivasi perawat baik melalui pemberian penghargaan berupa materi atau non materi (piagam disiplin atau piagam penghargaan) sehingga dapat meminimalisir adanya distres psikologis yang diterima perawat.

\section{KESIMPULAN DAN SARAN}

Penelitian ini menunjukkan bahwa distres psikologis berupa stres berat, kecemasan berat dan depresi minimal dialami hampir separuh perawat yang bekerja di RS Paru Sumatera Barat. Perawat yang bekerja diRawat Jalan mengalami stres berat, kecemasan berat dan depresi minimal selama bekerja pada pandemi Covid-19.Namun demikian, tingkat optimisme perawat yang bekerja di RS Paru Provinsi Sumatera Barat adalah tinggi.Adanya distres psikologis yaitu stres, kecemasan dan depresi pada perawat selama pandemi Covid-19 berhubungan dengan ruang bertugas dan optimisme.

Diharapkan pihak manajemen keperawatan di rumah sakit dapat meningkatkan lingkungan kerja yang kondusif untuk kenyamanan dalam bekerja, dukungan sosial berupa konseling bagi perawat dalam menghadapi masalah selama bekerja, adanya pergantian ruang bertugas perawat untuk meminimalkan distres psikologis, pemberian bonus bekerja selama pandemi Covid-19 dan adanya program yang nantinya akan berdampak baik bagi peningkatan pelayanan rumah sakit. Penelitian selanjutnya diharapkan diarahkan untuk mengidentifikasi intervensi yang dapat dilakukan untuk menurunkan distres psikologis yang dialami oleh perawat selama pandemi Covid-19.

\section{REFERENSI}

Assyahidah, N., \& Musabiq, S. (2014). Hubungan antara Optimisme dan Stres pada Mahasiswa Penerima Beasiswa Bidikmisi di Universitas Indonesia. Skripsi. Depok. Fakultas Psikologi. Univesitas Indonesia (online) diakses tanggal 16 September 2020.

Azzahra, F. (2017).Pengaruh Resiliensi Terhadap Distres Psikologis Pada Mahasiswa. Jurnal IImiah Psikologi terapan,5(1), 80-96.

BBC.com, (2020, 13 Agustus). Covid-19: Puskesmas dan rumah sakit tutup layanan akibat pandemi, layanan kesehatan dikhawairkan 'jebol' dalam enam bulan. Diakses tanggal 15 Agustus 2020 dari https://www.bbc.com/indonesia/indonesia53755057.amp

Canadian Institute for Health Information. (2012). The role of social support in reducing 
psychological distress. Ottawa, Canada:

Canadian Institute for Health Information

Chang, E. C., Rand, K. L., \& Strunk, D. R. (2000). Optimism and risk for job burnout among working college students: stress as a mediator, 29, 255-263.

Data Rumah Sakit Paru Sumatera Barat. (2018). Laporan Tahunan 2019 Edisi 2018.

Dewi, K. S. (2012). Kesehatan Mental Edisi 1. Semarang: UPT UNDIP Press Semarang.

Dimeitri, C., Hutapea, A., \& Mashoedi, S. R. I. F. (2019). The relationship between Optimism and Psychological Distress of Poor Emerging Adults in Jakarta, 10(2), 87-103.

Inter-Agency Standing Committee. (2020). Basic Psychosocial Skills: A Guide for COVID-19 Responders. Diakses 8 Agustus 2020 dari https://creativecommons.org/licenses/by-ncsa/3.0/igo

Koesmawardhani, N. W. (2020, Maret 17). Pemerintah Tetapkan Masa Darurat Bencana Corona hingga 29 Mei 2020. Diunduh dari https://news.detik.com/berita/d4942327/pemerintah-tetapkan-masa-dauratbencana-corona-hingga-29-mei-2020

Komalasari, I. G. (2018).Hubungan SelfCompassion dengan Optimisme pada Guru Sekolah Dasar Luar Biasa Negeri Di Jakarta.Skripsi.Fakultas Pendidikan Psikologi Universitas Negeri Jakarta.

Kompas.com, (2020, 12 Agustus). Pemkot Bogor Tutup 4 Puskesmas Usai 27 Pegawai Dinyatakan Positif Covid-19. Diakses tanggal 15 Agustus 2020 dari https://www.kompas.com/megapolitan/read/2 020/08/12/05484771/pemkot-bogor-tutup-4puskesmas-usai-27-pegawai-dinyatakanpositif-covid

Kompas.com. (2020, 13 Agustus). Berikut 4 RS yang Sempat Ditutup karena Tenaga Medisnya Terpapar Covid-19. Diakses tanggal 24 November 2020 dari https://www.kompas.com/tren/read/2020/08/1 3/080500665/berikut-4-rs-yang-sempatditutup-karena-tenaga-medisnya-terpaparcovid-19

Kroenke, K., Spitzer, R. L., \& Williams, J. B. W. (2001). The PHQ-9, 46202, 606-613.

Liu, Y. \& Liu, X. (2019).Mental distress among frontline healthcare workers outside the central epidemic area during the novel coronavirus disease ( COVID-19) outbreak in China: A cross-sectional study, 1-15. https://doi.org/10.21203/rs.3.rs-32833/v1
Mahastuti, P. D., I M., Luh, M. I. (2017). Perbedaan Stres Kerja pada Perawat di Ruang Unit Gawat Darurat dengan Perawat di Ruang Rawat Inap Rumah Sakit "S" di Kota Denpasar Tahun 2017, Vol. 10 Nomor 2: 284289.

Miller. A. V., et, al. (2011). The Decision Making Control Instrument Assess Voluntary Consent. The Children's Hospital of Philadelphia. https://doi.org/10.1177/0272989X11398666

Montalvan, V., Lee J., Bueso, T., De, T. J., Rivas, K. (2020). Neurological manifestations of COVID-19 and other coronavirus infections: $A$ systematic review, 194, 1-7.

Muliantino, M. R., dkk. (2020). Abstract Book The $7^{\text {th }}$ Virtual Padjajaran International Nursing Conference. Psychological Responses Among Indonesian Nurses in the Outbreak of Covid-19 Pandemic. Jatinagor: Fakultas Keperawatan Universitas Andalas.

Ningrum, D.W. 2011. Jurnal Psikologi. Hubungan Antara Optimisme dan Coping Stres pada Mahasiswa Universitas Esa Unggul yang Sedang Menyusun Skripsi, 9(01).

Sangitan, E. K. (2012). Cognitive Behavior Therapy Untuk Meningkatkan Keterampilan Sosial pada Mahasiswa yang Mengalami Distres Psikologis di Universitas Indonesia.Skripsi.Universitas Indonesia.

Satuan Tugas Penanganan COVID-19.(2020). Peta Sebaran Covid-19. August 14. Diakses tanggal 14 Agustus 2020 dari http://covid19.go.id/peta-sebaran

Scheier, M. F., \& Carver, C. (2015). Distinguishing Optimism From Neuroticism ( and Trait Anxiety, Self-Mastery, and Self-Esteem ): A Reevaluation of the Life Orientation Test, (December). https://doi.org/10.1037//00223514.67.6.1063

Scheier, M. F., Carver, C. S., and Bridges, M.W. (1994). Distinguishing Optimism From Neuroticism (and Trait Anxiety, Self-Mastery, and Self-Esteem): A Reevaluation of the Life Orientation Test.Journal of Personality and Social Psychology, 67(6) :10631078.https://doi.org/10.1037/00223514.67 .6 .1063

Sebayang, R. (2020, Januari 31). Awas! WHO Akhirnya tetapkan Corona Darurat Global. CNBC Indonesia. Di akses tanggal 13 Juli 2020 dari http://www.cnbindonesia.com/news/20200131 060856-4-134146/awas-who-akhirnyatetatpkan-corona-daruat-global 
Spitzer, R. L., Kroenke, K., Williams, J. B. W., \& Lo, B. (2015). A Brief Measure for Assessing Generalized Anxiety Disorder, 166, 10921097.

Surat Keputusan RS Paru Sumatera Barat Nomor 445.533/RSP/TU-Kepeg/V/2020 tentang perubahan alur pelayanan.

Waluyo, M. (2009). Psikologi Teknik Industri. Yogyakata: Graha IImu.

Wang, Z., Chen, J., Boyd, J. E., Zhang, H., Jia, X., Qiu, J., \& Xiao, Z. (2011). Psychometric Properties of the Chinese Version of the
Perceived Stress Scale in Policewomen, 6(12), 1-4. https://doi.org/10.1371/journal.pone.0028610

WHO Coronavirus Disease (COVID-19). WHO Dashboard. (2020) August 13. Diakses tanggal 13 Agustus 2020 dari https://covid19.who.int

Zhang, J., Lu, H., Zeng, H., Zhang, S., Du, Q., Jiang, T., Du, B. (2020). The differential psychological distress of populations affected by the COVID-19 pandemic. Brain, Behavior \& Immunity, 87, 49-50 